\title{
"A business transformation model to enhance the sustainability of small-sized family businesses"
}

\begin{tabular}{|c|c|}
\hline \multirow{4}{*}{ AUTHORS } & Anita Wijayanti (D) http://orcid.org/0000-0002-0579-7093 \\
\hline & Massila Kamalrudin (D https://orcid.org/0000-0003-4804-2042 \\
\hline & Safiah Sidek \\
\hline & Kartika Hendra Titisari (D) https://orcid.org/0000-0001-8214-2245 \\
\hline ARTICLE INFO & $\begin{array}{l}\text { Anita Wijayanti, Massila Kamalrudin, Safiah Sidek and Kartika Hendra Titisari } \\
\text { (2021). A business transformation model to enhance the sustainability of small- } \\
\text { sized family businesses. Problems and Perspectives in Management, 19(1), 185- } \\
\text { 197. doi:10.21511/ppm.19(1).2021.16 }\end{array}$ \\
\hline DOI & http://dx.doi.org/10.21511/ppm.19(1).2021.16 \\
\hline RELEASED ON & Friday, 26 February 2021 \\
\hline RECEIVED ON & Thursday, 03 December 2020 \\
\hline ACCEPTED ON & Wednesday, 10 February 2021 \\
\hline & $(\mathrm{ccc}) \mathrm{EY}$ \\
\hline LICENSE & $\begin{array}{l}\text { This work is licensed under a Creative Commons Attribution } 4.0 \text { International } \\
\text { License }\end{array}$ \\
\hline JOURNAL & "Problems and Perspectives in Management" \\
\hline ISSN PRINT & $1727-7051$ \\
\hline ISSN ONLINE & $1810-5467$ \\
\hline PUBLISHER & LLC "Consulting Publishing Company "Business Perspectives" \\
\hline FOUNDER & LLC "Consulting Publishing Company "Business Perspectives" \\
\hline$\sigma^{0}$ & 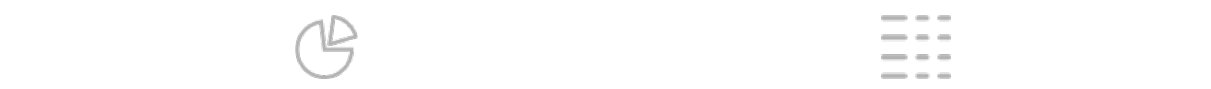 \\
\hline NUMBER OF REFERENCES & NUMBER OF FIGURES \\
\hline 35 & 2 \\
\hline
\end{tabular}

(c) The author(s) 2022. This publication is an open access article. 


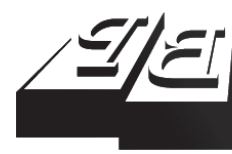

BUSINESS PERSPECTIVES

(2)

LLC "CPC "Business Perspectives" Hryhorii Skovoroda lane, 10, Sumy, 40022, Ukraine www.businessperspectives.org

Received on: $3^{\text {rd }}$ of December, 2020 Accepted on: 10 ${ }^{\text {th }}$ of February, 2021 Published on: $26^{\text {th }}$ of February, 2021

(c) Anita Wijayanti, Massila Kamalrudin, Safiah Sidek, Kartika Hendra Titisari, 2021

Anita Wijayanti, Master of Management, Lecturer, Islam Batik University, Surakarta, Central Java, Indonesia. (Corresponding author)

Massila Kamalrudin, Ph.D., Associate Professor, Universiti Teknikal Malaysia Melaka, Melaka, Malaysia.

Safiah Sidek, Bachelor of Business Administration, Lecturer, Universit Teknikal Malaysia Melaka, Melaka, Malaysia.

Kartika Hendra Titisari, Ph.D., Lecturer, Islam Batik University, Surakarta, Central Java, Indonesia.

This is an Open Access article distributed under the terms of the Creative Commons Attribution 4.0 International license, which permits unrestricted re-use, distribution, and reproduction in any medium, provided the original work is properly cited.

Conflict of interest statement: Author(s) reported no conflict of interest
Anita Wijayanti (Indonesia), Massila Kamalrudin (Malaysia), Safiah Sidek (Malaysia), Kartika Hendra Titisari (Indonesia)

\section{A BUSINESS TRANSFORMATION MODEL TO ENHANCE THE SUSTAINABILITY OF SMALL-SIZED FAMILY BUSINESSES}

\begin{abstract}
Business transformation is essential to making the small-sized family business more sustainable. Technological and environmental changes have radically transformed the way of doing business. Business transformation into digital business is the key to success in these conditions. On the other hand, some of the previous studies of business transformation in several countries and industries show different empirical evidence. This study analyzes the transformation process in a small-sized family business. This is a case study of 15 small-sized family businesses with four different types of industry, with an interview and observation period of 12 months in 2019-2020. This study has formulated a business transformation model for a small-sized family business and presented the results of the transformation process carried out. The research results indicate that a business transformation model consists of several attributes and sub-attributes. Business transformation results indicate different processes and times between companies. In general, the transformation process can be grouped into the exploration, learning, and synchronizing stages. The industry with the fastest transformation process is the hospitality industry, while the manufacturing process for the industry takes a bit longer. The results of this study indicate that business transformation has improved the sustainability of a small-sized family business that is characterized by its ability to adapt to changing technology and environmental conditions.
\end{abstract}

Keywords technology, transformation, digital, family business, model

JEL Classification $\quad$ M15, L26, L21

\section{INTRODUCTION}

Business transformation refers to the process of applying technology, which drastically changes business methods. Business transformation is a fundamental change in a company's business processes (Lundberg \& Sandberg, 2020). Small family businesses need business transformation to enhance sustainability. However, business transformation has become more difficult for the family businesses (Brenk et al., 2019) as their culture and status quo are very rigid and hard to change (Naldi et al., 2007). In this context, it is crucial for family businesses to find ways to become sustainable in the volatile and highly competitive environment. To enhance sustainability, family businesses can use innovative technology (de Massis, Frattini, \& Lichtenthaler, 2013; Hussin, 2005; Satalkina \& Steiner, 2020), strategy (Bigliardi et al., 2013; Sandlin, 2017; Siakas, Naaranoja, Vlachakis, \& Siakas, 2014), and a transformation business model into digital business (Amorim \& Melao, 2018; Kotarba, 2018; Prem, 2017; Schallmo, 2017; Ziyadin et al., 2020). The smallsized family business needs to respond to the changes and transform to become sustainable. 
However, business transformation into a digital business is very challenging. It is not only related to the organizational aspects, but also to the ethical, social, and regulatory aspects. Schallmo (2017) argued that some small-sized companies have failed to transform their process businesses into digital business. Further, Al-weshah and Al-zubi (2012) and Wijayanti (2018) argued that small-sized family businesses are not willing to transform to digital business because the digital business is less appropriate, less secure to family business, and its adoption is costly. This study analyzes the transformation process in a small-sized family business.

It has been argued that the key success of transformation process in the company is not only from the internal but also from the external factors of the company (Arunatileka, 2015; Prem, 2017; Schallmo, 2017). Drawing from the literature of business transformation, there are several views and suggestions on the process of business transformation. Arunatileka (2015) asserted seven stages in the transformation processes; the first stage in the transformation process is environment analysis. Schallmo (2017) explained five stages in the transformation process with eleven sub-stages in the process of corporate transformation, including external related stages, namely customers and distributors. Prem (2017) explained that there are 10 stages that need to be transformed with various sub-processes, including stages related to partners and customers. Kotarbba (2018) identified nine key activities involved in the business transformation, in which all of these stages are related to internal readiness.

Baran (2019) highlighted two main stages with eight business sub-processes in the process of transforming the company into the digital business. Different stages in the business transformation process also indicate the differences in business types and characteristics, having a different transformation process. However, the suggested transformation processes were drawn from non-family businesses, which is a lack of transformation business model in the family businesses.

Thus, to fill the gap, a business transformation model is proposed for small-sized family businesses. This study provides a theoretical contribution related to transformation business and practical contribution to the family business, in the context of family businesses' survival in the digital world. The paper is structured as follows: introduction, literature review consisting of the definition of family business and business transformation as the theoretical bases for the development of a family business transformation model, research methodology, research results showing the transformation model and the stages carried out by a family business, and a conclusion.

\section{LITERATURE REVIEW}

\subsection{Family business}

In general, the term family business is a company that is operated, managed and owned by a family or group of family members. Several descriptions of family business have been proposed. For example, a family business is considered as a company if the business involves two or more family members (Herrero, 2017). A business can also be considered as a family business when it involves two or more generations of the family and they have strong influence on the company policy (Bakoğlu et al., 2016). Family business exists when a family or a person of the related family owns at least $20 \%$ of the cash flow rights in the company either di- rectly or indirectly, through ownership of shares in both public and private entities (Memili, 2015). A family business usually starts with one owner, in which over time the family ownership of the business will transfer to the next generation (Goto, 2014; Satalkina \& Steiner, 2020; Steier et al., 2015; Yukselen \& Yildiz, 2014).

Business digitization has become a major concern for family businesses (Canterino et al., 2013; KPMG, 2017). Business digitization for family businesses refers to the adoption or the increased use of technology to change a business or improve its performance (Shani \& Brunelli, 2013). Based on a survey conducted by KPMG, it was explained that $48 \%$ of family businesses agreed to transform into a digital business, however $62 \%$ of respondents ex- 
perienced difficulties in transforming their business into a digital business, because they did not have experiences, resources, and abilities to lead the digital initiatives (KPMG, 2017). According to a survey conducted by $\mathrm{PwC}, 34 \%$ of family businesses respond to changes in digital business by developing a digital business strategy (PwC, 2018). Business transformation for the family business will be a separate challenge, apart from technical technology problems. The PWC survey also shows that conflicts within the family also affect the success of the family business's transformation process into a digital business (PwC, 2018).

\subsection{Business transformation}

Business transformation into digital business has various definitions, and one of the common concepts is to conceptualize transformation based on the concept of migration. Migration model is a digital transformation model that shows several stages of organizational changes in implementing the online business. Migration model emphasizes the company's capabilities, such as leadership and corporate culture (Krell \& Gale, 2005). The term "E-Transformation" has appeared at the beginning of 2010s. E-transformation is a term describing a company in changing its business processes into those based on technology. The new appearing term related to this issue is digital transformation. Digital transformation is a company's fundamental changing stages, including technology and social management, to a more innovative business model based on technology (Lundberg \& Sandberg, 2020).

Digital transformation refers to the changes made due to the technological changes (Arunatileka, 2015). Price Whaterhouse defines digital transformation as an effort to make an adjustment with new technology, which simultaneously affects the company (Price Watherhouse Cooper, 2017; Schallmo, 2017). Mazzone (2014) explains that digital transformation is a company's digital evolution processes, covering changes in business model, process and methodology, both strategically and tactically. Vial (2019) further explains that digital transformation is a process aiming at improving the company's performance due to the significant changes resulted from the changes in information, communication, comput- ing and connectivity technologies. Goerzig and Baurnhansl (2018) explain that digital transformation is a company's changes initiated by competitive advantage through the information technology evolution (Barann et al., 2019). Leuven (2019) states that digital transformation is a continuous interaction between digital technology, business and society, which have transformational effects on velocity, scope, and impact processes (Lundberg \& Sandberg, 2020).

Various descriptions of business transformation have been proposed by researchers. For example, transformation can be classified into three parts: strategic positioning (community and content), corporate strategy (collaboration, competition, and corporate change), and implementation strategy (computer and corporate change) (Arunatileka, 2015; Price Watherhouse Cooper, 2017, 2018). Kotarba (2018) developed e-transformation based on the ontology theory and highlighted the attributes of business transformation, including client segment, value proportion, client relationship, resources, channel, activity partnership, and finance. He further explained that digital transformation consists of three components: business transformation, digital technologies transformation, and society transformation. Schalmoo (2017) showed that the stages in digital transformation within a business transformation roadmap are digital reality, digital ambition, digital potential, digital fit, and digital implementation (Schallmo, 2017). A digitalization business model explains that several attributes in a company transformation to develop online business are partners, activities, resources, costs, products, and services, value propositions, customer relations, revenues, customer segments (Prem, 2017). Lundberg (2020) explains that digital transformation is divided into three stages: opportunity recognition (firm misalignment, environmental change, and innovative exploration), dynamic capabilities (scanning resources, evaluating outcome, and designing combination), and new value creation path (new values and new resources).

The seven Es in e-transformation explains that transformation model consists of several parts: environment analysis, e-transformation goal, E-(external/internal) readiness, transformation roadmap, e-transformation methodology, e-sys- 
tem (ICT, maintenance), and evolution-overall change (Arunatileka, 2015). (Barann et al., 2019) viewed that digital transformation for SMEs includes company position, creative digitalization roadmap, create supportive environment, digitalization project preparation, and solution implementation. Furthermore, Shani and Brunelli (2013) investigated transformation in Italian companies and identified three stages within the transformation process, consisting of present state (strategy, structure, process, and people), transformation state (radical action, security, strategy, vision, and redesign) and future state (effective result and capability change). The other study conducted by Krell and Gale (2005) explained that transforming business into digital business in e-commerce implementation, consisting of evaluating current business process, strategy and business model, possible and potential electronica choices, allows for a process and strategy business model, business strategy choices, architecture and finally new business, as well as organizational business process and strategy.

From the above discussions, it can be concluded that the family business has recently been forced to change its business model to a digital business. The small-sized family business is a family business that has fewer employees and/or less annual revenues than a regular-sized family business. In developing digital business, they need to collaborate with other small-sized family businesses. This is due to their lack of resources. To solve this problem, a small-sized family business has developed an online community business model, a digital-based business model that can be used in the community. Implementing this business model requires fundamental business changes called a business transformation. The stages in the transformation process will be discussed in this paper.

\section{AIMS AND RESEARCH METHODOLOGY}

Due to the need to transform the family business into online business model, this study aims to propose a transformation business model for a smallsized family business. Thus, a case study design was employed (Hollebeek et al., 2011; Robert K. Yin, 2003) to gain in-depth understanding on the transformation business processes experienced by the small-sized family business. This is a case study of 15 small-sized business family businesses with four different types of industry, with an interview and observation period of 12 months in 20192020. A case study was found to be an appropriate approach, since facilitating the data collection in the real-life contexts, elaboration theory was applied (Langley \& Abdallah, 2011) to broaden the important ideas of research on small-sized family business transformation processes. The use of multiple data sources could result in the transformation process phenomena of small-sized family businesses shown from different angles. Multiple data sources is a data source triangulation that can validate research data. This study was intended to understand the transformation process at various levels in several companies. Thus, a multiple case study was used to allow meaningful comparisons of all the transformations taking place.

\subsection{Respondent interviews}

In this study, 15 Indonesian small-sized family businesses were selected as the analysis units (cases) to participate in this study and transform into digital companies using the online community business model developed in the previous study. This study simultaneously involved individuals, groups, and companies as the research objects to analyze. Owners and managers of those smallsized family businesses have committed to adequately spare their time for this study. In this research, 33 participants were sampled, consisting of owners and managers of small-sized family businesses. An overview of the respondents involved in this study is presented in Table 1.

\subsection{Data collection}

The information was collected through a direct interview and observation from October to December 2019 based on the following stages. First, the researchers asked the company owners to make the socialization to the small-sized family business managers. Second, an in-depth interview was conducted with the owners related to various strategies and policies of the company's transformation processes in implementing an online community business model. The researchers also interviewed the managers 
Table 1. Case study interviewees

\begin{tabular}{|c|c|c|}
\hline Company & Industry & Interviewee \\
\hline \multirow{4}{*}{ Family Business A } & Batik Manufacture & S1. Owner (Mother) \\
\hline & \multirow{3}{*}{ Hotel } & S2. CEO (Daughter) \\
\hline & & S3. Hotel Operation Manager (Non-family Manager) \\
\hline & & S4. Manufacturing Manager (Non-family Manager) \\
\hline \multirow{6}{*}{ Family Business B } & Batik Manufacture & S5. Owner (Father) \\
\hline & Hotel & S6. Owner (Mother) \\
\hline & Coffee Shop & S7. Coffee Shop Manager (Daughter) \\
\hline & Restaurant & S8. Restaurant Manager (Brother-in-law) \\
\hline & \multirow{2}{*}{ Tour \& Travel } & S9. Hotel Manager (Son) \\
\hline & & S10. Operational Manager (Daughter) \\
\hline \multirow{6}{*}{ Family Business C } & Batik Manufacture & S11. Owner (Mother) \\
\hline & \multirow{5}{*}{ Hotel } & S12. CEO (Son) \\
\hline & & S13. Financial Manager (Daughter) \\
\hline & & S14. F\&B Manager (Daughter) \\
\hline & & S15. General Manager (brother-in-Law) \\
\hline & & S16. Marketing Manager (Non-family Manager) \\
\hline \multirow{6}{*}{ Family Business D } & \multirow{6}{*}{ Automotive } & S17. Owner (Father) \\
\hline & & S18. Owner (Mother) \\
\hline & & S19. Financial Manager (Daughter) \\
\hline & & S20. Operational Manager (Son) \\
\hline & & S21. Operational Manager (Brother-in-law) \\
\hline & & S22. Financial Manager (Sister-in-law) \\
\hline \multirow{7}{*}{ Family Business E } & \multirow{2}{*}{ Batik Manufacture } & S23. Owner (Father) \\
\hline & & S24. Owner (Mother) \\
\hline & Hotel & S25. Operational Manager (Daughter) \\
\hline & \multirow{4}{*}{ Restaurant } & S26. Marketing Manager (Non-family manager) \\
\hline & & S27. Operational Manager (Brother-in-law) \\
\hline & & S28. Financial Manager (Son) \\
\hline & & S29. General Manager (Non-family manager) \\
\hline \multirow{4}{*}{ Family Business F } & Batik Manufacture & S30. Owner (Daughter) \\
\hline & \multirow{3}{*}{ Hotel } & S32. CEO (Daughter) \\
\hline & & S32. Financial Manager (Brother-in-law) \\
\hline & & S33. Operational Manager (Brother-in-law) \\
\hline
\end{tabular}

involved in the company transformation process and responsible for the implementation of online community business model in the company's business processes. Some interviews were directly conducted in small-sized family business locations. Each interview session lasted up to two hours. For the next sessions, they were also interviewed through telephone calls lasting between 30 up to 90 minutes. The researchers recorded and copied all interviews by hand-writing and recording the information given. Especially during the first interview sessions, the researchers asked the interviewees to give their comprehensive actions in the transformation process. The researchers also openly asked the respondents and encouraged them to explain broadly and deeply in answers to all the questions asked.
Researchers have made observations starting from the initial stage of conducted transformation processes. The researchers' direct involvements in the small-sized family business transformation processes have given the explanations related to the transformation process stages. Fourth, the researchers also participated in 78 meetings in the form of focus group discussions (FGDs) with the companies' owners and managers, between managers and employers, as well as between managers (inter-manager) across the small-sized family businesses. Observations made at those various meetings confirmed the earlier findings.

\subsection{Thematic analysis}

Thematic analysis was employed in this study. The analysis was divided into three stages (Clarke \& 
Braun, 2013). In the first stage, the researchers conducted two activities by developing a code through the theoretical review about transformation and narration from data collections. Developing a code is an integration process, since the code can be obtained based on theoretical concepts developed in this study. The researchers developed narrations explaining each transformation process stage in a small-sized family business. The researchers built these narrations by tracing all raw data explaining the chronologies of each transformation stage. Along with Eisenhardt and Bourgeois (1988), the researchers then developed each narration between 5 to 25 pages in single-space format recording the transformation process activities in small-sized family businesses (Eisenhardt \& Bourgeois, 1988). The researchers analyzed the narration developed from various data sources to compile. They also gave particular codes in those narrations.

In the second stage, the researchers re-read all developed narrations, selected, and classified those codes based on issues, problems, solutions, and behaviors of business actors involving in the transformation process of the small-sized family business. The data were then processed in an open and axial code. To develop categories and subcategories, coding is a spiral process, from exploring ideas to connect between codes.

In the third stage, the narration results were reanalyzed to see the patterns based on each category. The focus was on the stages resulted from the models obtained from the transformation process and the descriptions of business actors' behaviors in the transformation processes. Through the multiple acrosscase analysis, building more abstract descriptions in each category and theme, several uniformity patterns have been found in those six small-sized family businesses to develop a transformation business model for a small-sized family business.

\section{RESULT}

\subsection{Small-sized family business technology}

Adapting to the changing business environment, small family businesses had to move from tradi- tional to digital businesses, and faced with various challenges in digital business development, small family businesses have agreed to mutually develop digital business technologies with larger families. Since a family business does not involve business collaboration, a community is created among family businesses, which is then formalized in the form of a strategic alliance. The strategic alliance among business families has decided to form a digital business technology based on the media platform of websites.

The developed platform consists of four elements with several attributes in each element. The elements in the family business platform include strategy, actor, business, and community. The attributes include platform owner, platform name, platform type, value production, and key activity, seller, customer support, other stakeholders, the platform manager, price discovery attribute, transaction content, key revenue system, price mechanism and revenue sources, content creation, reward and incentive, elicit participation, and control activity. The most fundamental difference is that there is community element in this platform model.

The developed platform needs to be adopted in the business processes made by a company. This technology will revolutionize the way small-sized family businesses operate and serve their customers. Thus, the small-sized family business required a proper business transformation to achieve the digitization of internal operational processes in the small-sized family business.

\subsection{Business transformation model for a small-sized family business}

The small-sized family business transformation business model was compiled based on the result of thematic analysis and the interconnection between theme and category in the attributes of the transformation model for small family business. The attributes can be divided into several sub-attributes. Thus, the key attribute platform consists of three attributes and nine sub-attributes.

Discussions with family business owners and managers, moderated by researchers, led to a family business transformation model. The results are shown in Figure 1. 


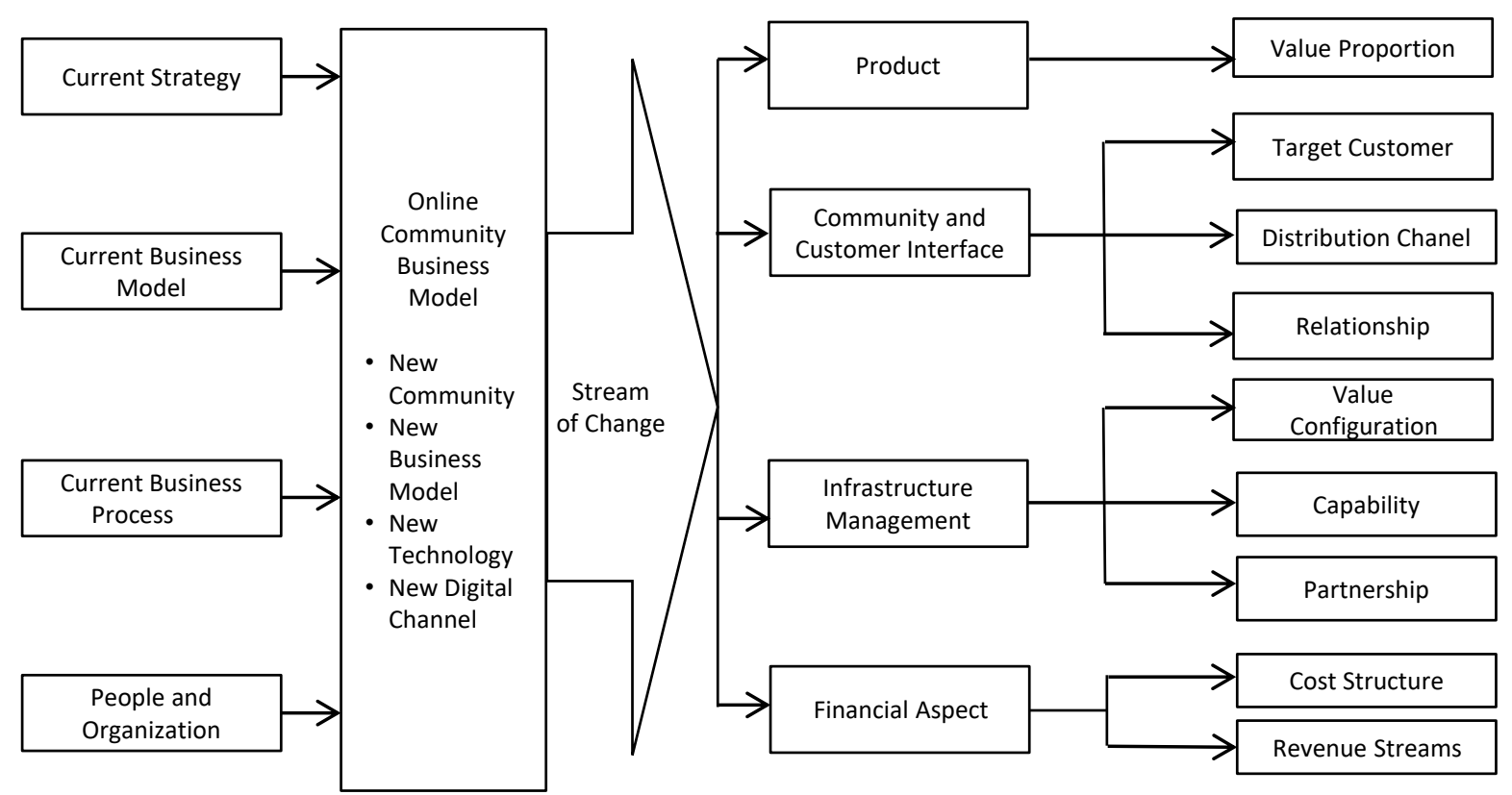

Figure 1. Family business transformation model

Table 2. Attributes and sub-attributes in a transformation business model

\begin{tabular}{c|c|c|c|c}
\hline Attributes & Product & $\begin{array}{c}\text { Community and customer } \\
\text { interface }\end{array}$ & Infrastructure management & Financial aspect \\
\hline \multirow{3}{*}{ Sub-attributes } & Value proportion & Target customer & Value configuration & Cost structure \\
& & Distribution channel & Capability & Revenue stream \\
& Relationship & Partnership & \\
\hline
\end{tabular}

Discussions with family business owners and managers, moderated by researchers, have resulted in the family business transformation model. In general, the changes made in small-sized family business within the transformation stages were included in the six company pillars consisting of product, community, customer, infrastructure, management, and finance.

a) Product. One step taken by a small-sized family business is to create firm value. In a forum group discussion, family business members determine new ways to meet their customers' needs. The results of discussions between family business members choose low prices and goods and services quality when delivering the products to consumers.

"... the price and quality of goods or services remain the main value proportion in every business unit that conducts business transformation. Ease of use and flexibility in purchasing a combina- tion of products into a value corporation in online transactions through a platform that has been developed" (Financial Manager, S28., Son, Family Business E).

b) Community and Customer Interface. In this pillar, there are three dimensions consisting of target customers, distributor channels, and relationships. The results of discussions with small-sized family business members show that the target customer is a traveler visiting Laweyan, a traditional village in Surakarta, Central Java, Indonesia.

"......we agree that the target customer is a traveler who will visit Surakarta, Indonesia, specifically in the traditional village of Laweyan. They will more easily use the platform that we have built to prepare their visit to Surakarta, Indonesia. They can directly book hotels, travel, and food available on the platform. Expansion of market segments and customer loyalty is our hope for this transfor- 
mation" (Marketing Manager, S16, Non-family Manager, Family Business C).

There are 15 types of businesses, from six smallsized family businesses, joining the established community business; they become a partner channel for the other business units. This has been mutually agreed in the strategic alliance and business platform development by the small-sized family business.

"....We have agreed that businesses under a family business that are members of a community business will mutually become partner distributor channels ... for example, hotel customers will be able to book tour packages on tour and travel partners. This has been agreed in a strategic alliance, one of which is the establishment of a business platform." (Owner, S6, Mother, Family Business B).

The transformation process in each business unit in a small-sized family business will involve all members in the small-sized family business as the members of business community. The members of a small-sized family business involved in this transformation must work together not only within one firm but also across the firms. The community business will strengthen the relationship between family business members. A strong relationship will become strength in the transformation process.

“... small-sized family business must develop cooperation not only within one firm but also across family businesses, so it requires strong relationships. We have a business community that can strengthen relationships between members. Relationship will strengthen the process of business transformation" (Operational Manager, S20, Son, Family Business C).

c) Infrastructure and management. In this pillar, there are three dimensions of the business transformation process for small-sized family businesses covering value configuration, capability, and partnership. Business units in small-sized family businesses, operational changes in the process of receiving orders, product preparation, and product delivery. As an example, one business unit in a small family business places a special part to manage orders and deliver products/services ordered through a business platform. This section is coordinated with other small-sized family business sections when there is a product order involving in a business unit with another small-sized family business.

"Our coffee shop has a special section that will handle and monitor orders through the platform, while this section will coordinate with other family businesses so that the product delivery process is in line with consumer expectations" (Coffee Shop Manager, S7, Daughter, Family Business B).

The main capability owned by a small-sized family business is management and strong human resources. Changes in a business model will also change the management process. This change is the main point in the business transformation process. Failure in the process of implementing management according to the new business model is a failure of a business transformation process. According to the observations, management in small-sized family businesses can adjust the new business models applied. The human resources willing to learn and change in accordance with the direction of business transformation will strengthen small-sized family businesses.

"Capability in human resources and management has become one of the strengths in the business transformation small-sized family business. Their bravery and ability to change is one of the central decision by the SDM in managing to transform the small-sized family business into digital business" (Owner, S24, Mother, Family Business E).

Partnership plays a significant role in the transformation success of a small-sized family business. The partnership initiatives involve inter-partnership between owners and management, management and employees, owners and employees within a particular business. Besides, partnership among owners, managements, and employees also exists among different family businesses leading to the strategic alliances.

“... the partnership among owners, managements, and employees within a particular family business seems to become stronger in the process of transformation ... . Partnership with owners, managements, and employees from other business families also 
facilitates the process of business transformation in situations where they conduct projects together." (F\&B Manager, S14, Daughter, Family Business C).

d) There are two dimensions of the financial aspect, covering cost structure and revenue stream. Cost structure, specifically a value-driven one, in the transformation process for business is supported by a small-sized family business, while cost-driven, which is to minimize the cost of products or services is fulfilled by the individual business unit. The revenue stream for a small-sized family business refers to the price paid by customers based on the transaction.

"The transformation process for cost structure is fully supported by the individual business unit, while the revenue stream is the volume of a transaction from the price paid by customers." (Financial Manager S28., Son, Family Business E).

Based on the above explanations, transformation generally has the following several stages: 1) preparing the products to sell through online media to increase value for customers, 2) the role of community business in creating the costumers' loyalty and cooperation among family businesses, 3) infrastructure in receiving online orders and management, as well as those involved in management changes, 4) cost for the operation and implementation of a business model, as well as the arranged revenue stream. The activities made to support the transformation stages of small-sized family business include the development of value proportion as one company strategy, target-customer determination, distributor channels either with suppliers or customers, relationship to strengthen the created community, infrastructure, and processing management, as well as the partnership strengthening family businesses to improve the capabilities of an online community business model, run the cost-sharing based on the agreed cost structure and develop a platform as the revenue stream bases.

\subsection{Small-sized family business transformation process}

Focus group discussion was used to see the process and length of the transformation period required by each small-size family business. The transformation process conducted using a transformation business model, indicated several stages of transformation made by the small family businesses.

"We are conducting the stages of transformation process for a model developed, yet no significant impact, for about 1 month. We remain consistent in implementing various stages in the business transformation model. The synchronization between traditional business and digital business will occur in the fourth month. At this stage, many employees begin to understand new business processes and customers who have taken advantage of the developed business platform. We continue to consistently optimize the transformation process so that our business processes have become a digital business." (Owner, S23, Father, Family Business E).

"We followed all stages in the developed transformation model. In the first month, there was no significant impact on changes in our HR and sales. In that first month, we then synchronized the old system existed in our hotel. In the second month, there was an impact on business processes due to the well-synchronized existing system. In the third month, we have been able to adopt a website-based technology platform in our business processes, and it can be concluded that our transformation process into a digital business has been successful" (Hotel Manager, S9, Son, Family Business B).

From the discussions above, it can be concluded that there were three stages in the business transformation process made by small-sized family businesses:

1. Exploration: a small-sized family business tries to transform its business but does not have a significant impact on the small-sized family business.

2. Learning: business transformation requires all members in a small-sized family business to learn the digital business concept.

3. Synchronization: synchronize new business models and replace old business processes.

Different transformation process periods in each industrial type are presented in Figure 2. 


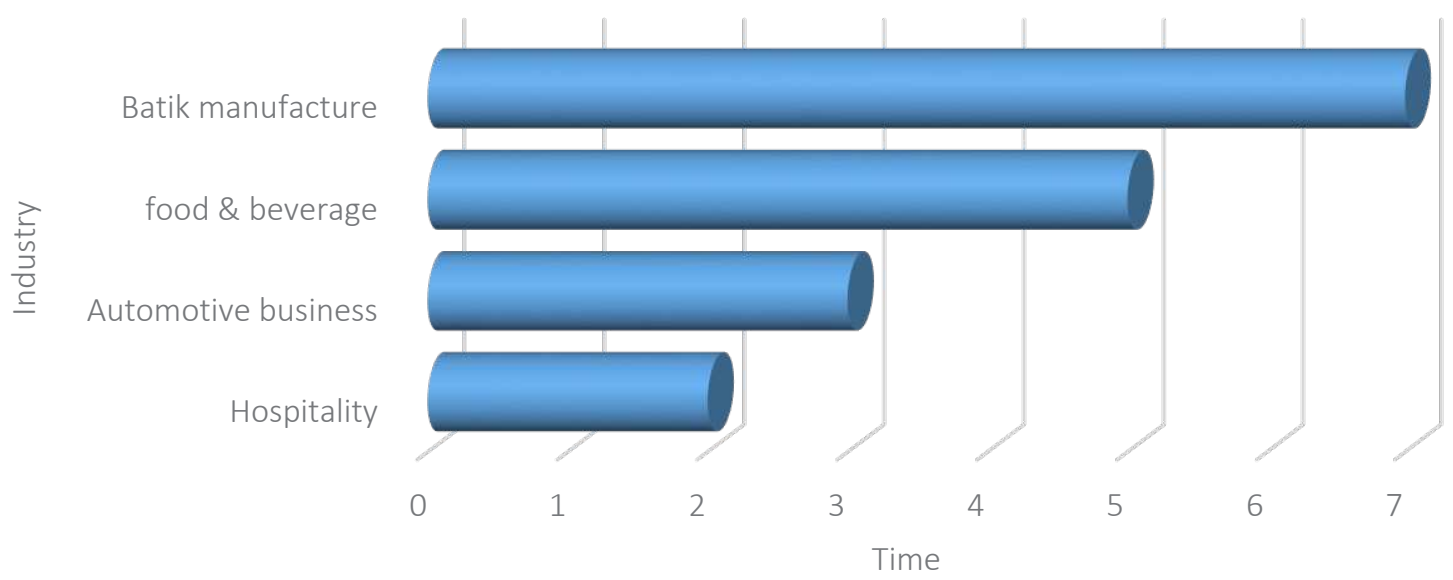

Figure 2. Small-sized family business transformation periods

The result showed that business units in the form of hospitality industry required the shortest time to integrate an online community business model with its business processes. In two months, the online community business model had been integrated with its businesses. The transformation made for its hospitality business unit had rapidly developed, since the previous one had joined several marketplaces in the field of hospitality industries that the data were related to the earned costs and revenues. The implementation of an online community business model did not change its costs and revenues. Infrastructure and management in the hospitality business unit were ready to face changes.

The automotive business unit also required a relatively long time of about three months, since this type of a business unit did not have too many processes. There were relatively few products marketed. The problems were mainly related to limited infrastructures, mindset changes, and management attitudes. A business unit operating in food and beverage industries (restaurant and coffee shop) had a transformation time of five months to integrate the online community business with its business processes. Batik manufacture business unit had the longest transformation time of more than seven months, since manufacturing business processes were relatively more complex and complicated, so they did not completely transform and implement the online business model.

\section{DISCUSSION}

The transformation of these six pillars of smallsized family businesses is similar to the online busi- ness model developed by Kotarba (2018), in which the developed model was inspired by Osterwalder (2002). The researchers believe that the transformation model in the small-sized family business may be well developed based on those underlying theories, even there is a small difference, wherein the previous model has four pillars such as product, customer interface, infrastructure management, and financial aspect. Adjustment is made by combining the pillars of communities and customers, as well as infrastructure and management. Thus, the small-sized family business transformation model is defined into four pillars as the bases in the small-sized family business transformation processes consisting of product, community and customer, infrastructure and management, and financial aspects.

The transformation model for small-sized family businesses developed in this study is in line with the stages in the transformation model proposed by Arunatileka (2015), Shani and Brunelli (2013), and Krell and Gale (2005), who explain the stages of environmental analysis or analysis of the current business process, strategy and business model. The transformation model developed by Arunatileka (2015), Schallmo (2017), Krell and Gale (2005), and Kotarba (2018) described the stages of setting transformation goals, while the transformation model for small-sized family businesses and transformation goals are at the value proportion stage.

The e-readiness stage as contained in Arunatileka (2015) is not present in the transformation model for small-sized family businesses because the small-sized family businesses participated in this 
study show their readiness to perform business transformation with its consequences. This is in line with some of the transformation models developed by Kotarba (2018) and Prem (2017). The system discussed in the transformation model for small-sized family businesses is only a business system called a business process, for technology systems it is not discussed in detail in this model because it will be discussed in other studies. This is in line with the model developed by Prem (2017), Shani and Brunelli (2013), and Krell and Gale (2005). The transformation model developed in this study does not use the partnership stage, as proposed by Prem (2017) and Kotarba (2018), but the relationship stage. The business transformation process by a small-sized family business is an attempt to implement an online community business model, when the model is developed based on a partnership between several small-sized family businesses. Therefore, relationship is an important stage in the transformation model for small-sized family businesses, as a process to strengthen partnerships among small-sized family businesses.

In several aspects. the business transformation model for small-sized family businesses is in line with the results of previous studies (Arunatileka, 2015; Krell \& Gale, 2005; Prem, 2017; Schallmo, 2017). Several researchers have also confirmed that these models can be the direction for the corporate business transformation (Kotarba, 2018). The model developed can also be made in small businesses, since its stages are also available in the research conducted by Barann (2019) and Kotarba (2018). Different company types used as respondents have resulted in different stages of the transformation process.

The findings of this study enrich the key organizational features leading to the development of the transformation concept presentation. Further research is urgently needed to ensure that the family business transformation model may be well implemented in different companies. Future researchers may generalize the use of this model in other companies. Observations on the success of the above transformation model should be reviewed regularly as information technology is constantly evolving. A small family business should make ongoing activities to adjust the changes in its business processes.

\section{CONCLUSION}

This study has formulated a business transformation model for a small family business. It finds a transformation model that fits the characteristics of a small-sized family business and presents the results of the transformation process carried out. A significant finding from this study is a business transformation model consisting of several attributes and sub-attributes. Thus, those four attributes are integrated into the small-sized family business transformation model consisting of product, community and customer interface, infrastructure, management, and financial aspect, and nine sub-attributes covering value proportion, target customer, distribution channel, relationship, value configuration, capability, partnership, cost structure, and revenue stream. Attributes and sub-attributes in the business transformation model are part of a small-sized family business that needs to change as it adapts to digital business. The transformation process carried out can be grouped into exploration, learning, and synchronizing stages. The fastest time for a business transformation process is in the hospitality industry, and the longest time for transformation is in the manufacturing industry.

The results of this study show that the business transformation that has taken place has increased the company's sustainability as small-sized family businesses can adapt to changing technology and environmental conditions. Further research can change the type and size of the company as a subject of research, and this can increase the diversity of contributions to business transformation theory, so that companies can have a reference in the business transformation process according to the type of industry. 


\section{AUTHOR CONTRIBUTIONS}

Conceptualization: Anita Wijayanti.

Data curation: Kartika Hendra Titisari.

Formal analysis: Anita Wijayanti.

Funding acquisition: Anita Wijayanti, Massila Kamalrudin, Safiah Sidek.

Investigation: Massila Kamalrudin, Safiah Sidek.

Methodology: Anita Wijayanti.

Project administration: Kartika Hendra Titisari.

Resources: Anita Wijayanti.

Validation: Massila Kamalrudin, Safiah Sidek.

Writing - original draft: Anita Wijayanti.

Writing - review \& editing: Anita Wijayanti, Kartika Hendra Titisari.

\section{REFERENCES}

1. Al-weshah, G., \& Al-zubi, K. (2012). E-Business Enablers and Barriers: Empirical Study of SMEs in Jordanian Communication Sector. Global Journal of Business Research, 6(3). Retrieved from http://www.theibfr2.com/RePEc/ ibf/gjbres/gjbr-v6n3-2012/GJBRV6N3-2012-1.pdf

2. Arunatilek, S. (2015). The Seven E'S In e-Transformation - A Strategic E Transformation Model. In IADIS International Conference e-Society.

3. Bakoğlu, R., Bige, O., \& Yildırım, A. (2016). The Role of Sustainability in Long Term Survival of Family Business : Henokiens Revisited. Procedia Social and Behavioral Sciences, 235(October), 788-796. https://doi. org/10.1016/j.sbspro.2016.11.081

4. Barann, B., Hermann, A., \& Chasin, F. (2019). Supporting Digital Transformation in Small and Medium-sized Enterprises : A Procedure Model Involving Publicly Funded Support Units. In The 52nd Hawaii International Conference on System Science (Vol. 6, pp. 4977-4986). Retrieved from https://core.ac.uk/download/ pdf/211327678.pdf

5. Bigliardi, B., Cassia, L., De Massis, A., \& Frattini, F. (2013). Technology strategy in a family business: A new avenue for research. International Journal of Entrepreneurship and Innovation Management, 17(1-
3), 1-7. https://doi.org/10.1504/ IJEIM.2013.055262

6. Canterino, F., Cirella, S., Guerci, M., Shani, A. B., \& Brunelli, M. S. (2013). Leading transformation in a familyowned business: Insights from an Italian company. International Journal of Entrepreneurship and Innovation Management, 17(1-3), 54-83. https://doi.org/10.1504/ IJEIM.2013.055248

7. Clarke, V., \& Braun, V. (2013). Teaching thematic analysis: Overcoming challenges and developing strategies for effective learning. Psychologist, 26(2), 120 123. http://dx.doi.org/10.1191/ 1478088706qp063oa

8. De Massis, A., Frattini, F., \& Lichtenthaler, U. (2013). Research on Technological Innovation in Family Firms: Present Debates and Future Directions. Family Business Review, 26(1), 10-31. https://doi. org/10.1177/0894486512466258

9. Eisenhardt, K. M., \& Bourgeois, L. J. (1988). Politics of Strategic Decision Making in High-Velocity Environments: Toward a Midrange Theory. Academy of Management Journal, 31(4), 737-770. https://doi. org/10.5465/256337

10. Goto, T. (2014). Family Business and Its Longevity. Kindai Management Review, 2, 78-96. Retrieved from https://www.semanticscholar.org/paper/Family-
Business-and-Its-Longevity-Goto/ 9a6bffa3aebe867fc0d17e9430b5e7 daf4288edf

11. Herrero, I. (2017). Family Involvement and Sustainable Family Business: Analysing Their Effects on Diversification Strategies. Sustainability, 1-20. https://doi.org/10.3390/su9112099

12. Hollebeek, L. D., Juric, B., \& Ilic, A. (2011). Customer engagement: Conceptual domain, fundamental propositions, and implications for research (May 2019). https://doi.org /10.1177\%2F1094670511411703

13. Hussin, H. (2005). Innovating Business Through E-Commerce: Exploring The Willingness Of Malaysia SMEs. In The Second International Conference On Innovation In IT (pp. 1-10).

14. Kotarba, M. (2018). Digital Transformation of Business Models. Foundation of Management, 10, 123-142. https:// doi.org/10.2478/fman-2018-0011

15. KPMG. (2017). Family businesses in the digital economy Foreword. Retrieved from https://assets. $\mathrm{kpmg} /$ content/dam/kpmg/sg/ pdf/2017/05/Family-Businessesin-the-Digital-Economy.pdf

16. Krell, T., \& Gale, J. (2005). E-business Migration : A Process Model. Journal of Organizational Change Management, 18(2), 117-131. https://doi. org/10.1108/09534810510589552 
17. Langley, A., \& Abdallah, C. (2011). Templates and turns in qualitative studies of strategy and management. Research Methodology in Strategy and Management, 6(April), 201-235. https://doi.org/10.1108/S14798387(2011)0000006007

18. Lundberg, O., \& Sandberg, J. (2020). Cycles of Innovation and Alignment in Digital Transformation: Investigating the Dynamics of Resource Recombination in a Construction Firm Cycles of Innovation and Alignment in Digital Transformation: Investigating the Dynamics of Resource Recombination. In 53rd Hawaii International Conference on System Science. https://doi.org/10.24251/ HICSS.2020.531

19. Memili, E. (2015). Performance and Behavior of Family Firms. International Journal of Financial Studies, 3(3), 423-430. https://doi. org/10.3390/ijfs3030423

20. Osterwalder, A. (2002). E-Business Model Design, Classification, and Measurements, 44(February), 5-23. https://doi. org/10.1002/TIE.1036

21. Prem, E. (2017). A digital transformation business model for innovation. International Journal of Innovation Management, 21(September). Retrieved from https://www.researchgate.net/ publication/284682831_A_digital_ transformation_business_model_ for_innovation

22. Price Waterhouse Cooper. (2017). A Decade of Digital Keeping Pace with Transformation Looking Back to Look Forward. Retrieved from https://www.pwc.com/ee/et/publications/pub/pwc-digital-iq-report. pdf

23. Price Waterhouse Cooper. (2018). New Business Models in The e-Commerce Era. Retrieved from https://www.pwc.com/co/es/industrias/Retail/insights/biz_model_vf.pdf

24. Price Waterhouse Cooper. (2018). Family Business Survey 2018. Retrieved from https://www.pwc. com/id/en/epc/fbs-2018-indonesia.pdf
25. Robert K. Yin. (2003). Case Study Research: Design and Method. (3rd ed.). Thousand Oaks, CA: Sage.

26. Reis, J., Amorim, M., Melao, N., \& Matos, P. (2018). Digital Transformation: A Literature Review and Guidelines for Future Research. In: Rocha Á., Adeli H., Reis L.P., Costanzo S. (eds) Trends and Advances in Information Systems and Technologies. WorldCIST'18 2018. Advances in Intelligent Systems and Computing, vol 745. Springer, Cham. https:// doi.org/10.1007/978-3-319-777030_41

27. Sandlin, J. (2017). Family Business Adaptation to Disruptive Technology. Jonkoping University.

28. Satalkina, L., \& Steiner, G. (2020). Digital entrepreneurship and its role in innovation systems: A systematic literature review as a basis for future research avenues for sustainable transitions. Sustainability (Switzerland), 12(7). https://doi.org/10.3390/ su12072764

29. Schallmo, D. (2017). Digital Transformation Of Business Models - Best Practise, Enablers, and Roadmap. International Journal of Innovation Management, 21(8), 1-17. https://doi.org/10.1142/ S136391961740014X

30. Shani, A. B., \& Brunelli, M. S. (2013). Leading transformation in a family-owned business: Insights from an Italian company. International Journal Entrepreneurship and Innovation Management, 17(January). https://doi.org/10.1504/ IJEIM.2013.055248

31. Siakas, K., Naaranoja, M., Vlachakis, S., \& Siakas, E. (2014). Family Businesses in the New Economy: How to Survive and Develop in Times of Financial Crisis. Procedia Economics and Finance, 9(14), 331341. https://doi.org/10.1016/S22125671(14)00034-3

32. Steier, L. P., Chrisman, J. J., \& Chua, J. H. (2015). Governance Challenges in Family Businesses and Business Families. Entrepreneurship Theory and Practice, 1265-1280. https://doi. org/10.1111/etap.12180
33. Wijayanti, A. (2018). Factors Contributing Online Family Business To Enhance The Sustainability of Family Business. The Turkish Online Journal of Design, Art, and Communication, September, 3114-3120. DOI $10.7456 / 1080$ SSE/388

34. Yukselen, C., \& Yildiz, E. (2014). The Role of The Family Constitution in Sustainability of Family Business and Evaluation in Light of Implementation Problem. Research Journal of Business and Management, 1(1), 14-28. Retrieved from https://dergipark.org.tr/tr/download/articlefile/375233

35. Ziyadin, S., Suieubayeva, S., \& Utegenova, A. (2020). Digital Transformation in Business. Lecture Notes in Networks and Systems, 84(September 2019), 408415. https://doi.org/10.1007/9783-030-27015-5_49 